\title{
Wijzigingen corporate governance en de gevolgen voor het directieverslag
}

\section{Auke de Bos, Henk Edelman, Mijntje Lückerath-Rovers en Margot Scheltema}

SAMENVATTING Als gevolg van gewijzigde wet- en regelgeving dienen beursgenoteerde ondernemingen meer corporate governance-informatie op te nemen.

Samengevat gaat het hierbij om:

- de verklaring inzake corporate governance als gevolg van het Besluit tot vaststelling van nadere voorschriften omtrent de inhoud van het jaarverslag;

- de 'in-control statement' ten aanzien van financiële verslaggevingsrisico's, zoals in de herziene Nederlandse Corporate Governance Code verduidelijkt;

- de bestuursverklaring als gevolg van de Wet op het financieel toezicht.

Doordat deze informatievereisten op meerdere plaatsen in wet- en regelgeving zijn opgenomen, waarbij definities verschillend geïnterpreteerd lijken te worden, kan dit tot onduidelijkheden leiden. Uit ons jaarrapportenonderzoek komt een uiteenlopende

verslaggevingspraktijk naar voren. Dit kan een signaal zijn dat de huidige wet- en regelgeving voor de directies lastig te interpreteren is. De uiteenlopende verslaggevingspraktijk draagt in ieder geval niet bij aan een begrijpelijke informatieverstrekking aan de gebruikers van de jaarrapporten. Dit is ons inziens een niet-wenselijke situatie. Wij pleiten dan ook voor een aantal aanpassingen in de wet- en regelgeving dat moet bijdragen aan een consistente en begrijpelijke verslaggeving op het gebied van corporate governance-informatie.

\section{RELEVANTIE VOOR DE PRAKTIJK De wijzigingen van de Nederlandse Corporate}

Governance Code, het aangepaste Besluit tot vaststelling van nadere voorschriften omtrent de inhoud van het jaarverslag en de Wet op het financieel toezicht hebben gevolgen voor de te verstrekken informatie op het gebied van corporate governance. In dit artikel wordt ingegaan op een aantal belangrijke wijzigingen in de wet- en regelgeving en de wijze waarop ondernemingen hier invulling aan geven. Tevens komen wij met enkele praktische aanbevelingen voor de wet- en regelgever.

\section{Inleiding}

Recent heeft een aantal wijzigingen plaatsgevonden met betrekking tot de wet- en regelgeving omtrent informatieverschaffing van de directie op het gebied van corporate gover- nance. Deze wijzigingen hebben plaatsgevonden in het burgerlijk wetboek (hierna: BW), in de Wet op het financieel toezicht (hierna: Wft), in het Besluit tot vaststelling van nadere voorschriften omtrent de inhoud van het jaarverslag (hierna: Besluit) en in de Nederlandse Corporate Governance Code (hierna: Code). Blijkbaar was er behoefte bij wet- en regelgevers om concreter aan te geven welke corporate governance-informatie zij belangrijk vonden. Het feit echter dat deze informatievereisten op meerdere plaatsen in wet- en regelgeving zijn opgenomen, waarbij definities verschillend geïnterpreteerd lijken te worden, kan tot onduidelijkheid leiden.

In dit artikel brengen wij de verschillende eisen in kaart en onderzoeken wij hoe de ondernemingen de wet- en regelgeving in de praktijk toepassen. Tevens hebben wij enkele opvallende practices opgenomen waaruit de uiteenlopende praktijk blijkt. Wij hebben de jaarrapporten onderzocht van ondernemingen met een notering aan de AEX en AMX.

Ook staan wij stil bij de vraag waar de informatie wordt opgenomen in het jaarrapport. Terminologie rondom het jaarrapport wordt vaak verschillend geïnterpreteerd. Zo wordt in de volksmond regelmatig met 'jaarverslag' het gehele gedrukte jaarrapport bedoeld. De term jaarverslag is echter in de wet gedefinieerd in artikel $391 \mathrm{BW} 2 \mathrm{en}$ betreft louter het (geschreven) verslag van de directie. In ons onderzoek is dit de definitie die wij hanteren voor 'het directieverslag'. Voor dit artikel hanteren wij verder de volgende terminologie.

Het jaarrapport is het gehele rapport dat ondernemingen jaarlijks publiceren, bestaande uit:

- Directieverslag: in artikel $391 \mathrm{BW} 2$ genoemd het "jaarverslag'. Hieronder valt ook informatie die door middel van verwijzing deel uitmaakt van het directieverslag.

- Overige informatie bij het directieverslag: aan directieverslag gerelateerde informatie die formeel geen onderdeel is van het directieverslag, zoals aandeelhoudersin- 
formatie, remuneratiehoofdstuk, belangrijke ratio's, enzovoort.

- Verslag van de Raad van Commissarissen.

- Bestuursverklaring: verklaring die het bestuur dient af te leggen omtrent de getrouwheid van de jaarrekening en het directieverslag.

- Jaarrekening: de balans, winst- en verliesrekening, en toelichting zoals bedoeld in artikel $361 \mathrm{BW} 2$.

- Overige gegevens: de overige gegevens bij de jaarrekening en jaarverslag zoals bedoeld in artikel 392 BW 2.

In dit artikel zullen wij vooral stilstaan bij de corporate governance-informatie die opgenomen dient te worden in het directieverslag.

\section{Wet- en regelgeving}

Volgens de 'agency theory' kan spanning bestaan tussen de belangen van de aandeelhouders en de directie van een onderneming. Hiervoor zijn wetten en regels ten aanzien van corporate governance opgesteld (De Ridder en Steggink 2009). In dit artikel behandelen wij artikel 391 BW 2, het Besluit, de Code en de Wft, waarin eisen worden gesteld ten aanzien van informatieverschaffing op het gebied van corporate governance.

Op het gebied van het directieverslag heeft zich een aantal relevante wijzigingen in de wet- en regelgeving voorgedaan met ingang van boekjaar 2009. Deze resulteren in de corporate governance-verklaring, in-control statement en bestuursverklaring en worden hierna nader uitgewerkt.

Opvallend is dat een aantal aspecten behandeld is in meerdere wetten en regels. In de bijlage is een matrix overgenomen van alle onderwerpen die aan bod komen in de verschillende uitingen van wet- en regelgeving (zie bijlage 2). Hieruit blijkt dat de onderlinge samenhang van de diverse bepalingen complex is geworden.

\subsection{Artikel 391 BW 2}

Artikel 391 BW 2 betreft de informatie die opgenomen dient te worden in het directieverslag. Lid 5 stelt dat bij algemene maatregel van bestuur nadere voorschriften kunnen worden gesteld omtrent de inhoud van het directieverslag. Hierin werden reeds eisen gesteld aan de te hanteren gedragscode. Vanaf 2009 kunnen er ook nadere voorschriften worden gesteld ten aanzien van de inhoud, de openbaarmaking en het accountantsonderzoek van een 'verklaring inzake corporate governance'.

\subsection{Besluit}

Het invoeren van het Besluit in 2004 was mede het gevolg van de Vierde EC Richtlijn, doorgaans de Corporate Governance Richtlijn genoemd (2006/46/EC), waarmee corporate governance-codes in nationale wetgeving werden verankerd. De hiervoor genoemde nadere voorschriften zijn in 2009 uitgewerkt in het Besluit. ${ }^{1}$ De wijzigingen hebben betrekking op boekjaren beginnend op of na 1 januari 2009. Het Besluit wijst in artikel 2 de herziene Code aan als de gedragscode waarop gedoeld wordt in artikel 391 lid $5 .{ }^{2}$ Artikel $2 a$ lid 1 van het Besluit vereist dat het bestuur een 'verklaring inzake corporate governance' publiceert. Deze corporate governance-verklaring wordt openbaar gemaakt in het directieverslag of wordt op de website geplaatst. Indien de corporate governance-verklaring wordt opgenomen in het directieverslag, kan dit ofwel als onderdeel van het directieverslag ofwel als bijlage. Indien de directie de corporate governance-verklaring openbaar maakt via plaatsing op de website, dient deze rechtstreeks en permanent toegankelijk te zijn en dient het directieverslag een verwijzing te bevatten. De corporate governance-verklaring wordt altijd geacht deel uit te maken van het directieverslag, ook als deze bijgevoegd is als bijlage of is geplaatst op de website.

De corporate governance-verklaring dient een aantal aspecten te bevatten (zie bijlage 1 voor een uitgebreide opsomming) waaronder:

- een uitspraak betreffende de naleving van de principes en best practice-bepalingen van de Code;

- een mededeling over de belangrijkste kenmerken van het beheers- en controlesysteem van de vennootschap met betrekking tot de financiële verslaggeving;

- een mededeling over het functioneren van de aandeelhoudersvergadering;

- een mededeling over de samenstelling en het functioneren van het bestuur, de raad van commissarissen en de commissies van de raad van commissarissen;

- een mededeling ingevolge artikel 1 lid 1 van het besluit overnamerichtlijn;

- een lijst van namen met een bijzonder statutair recht op het gebied van de zeggenschap.

Bijzonder is dat hier expliciet gevraagd wordt naar het functioneren van de diverse organen betrokken bij de vennootschap. Het gaat hierbij ons inziens niet om het verstrekken van een waardeoordeel omtrent het functioneren, maar om het toelichten van een antal formele aspecten zoals bevoegdheden en het aantal vergaderingen.

\subsection{Code}

Op 10 december 2008 presenteerde de Monitoring Commissie Corporate Governance Code onder leiding van Jean Frijns de gewijzigde Code, die net als het Besluit van toepassing is op boekjaren beginnend op of na 1 januari 2009. Deze Code is in december 2009 via het Besluit wettelijk verankerd. De herziene Code bevat onder meer een aantal wijzigingen die relevant zijn voor het directieverslag. Zo zijn bijvoorbeeld de 
eisen ten aanzien van de inhoud van het directieverslag uitgebreid met de hoofdzaken van de voor de onderneming relevante maatschappelijke aspecten van ondernemen (bepaling II.1.2 Code). Deze wijziging valt echter buiten de reikwijdte van ons onderzoek.

De herziene Code maakt op het gebied van risico's een tweedeling. In de oude versie van de Code van 2004 werden strategische, operationele, financiële, financiële verslaggevings- en compliancerisico's als gelijkwaardig behandeld als objecten waarop een toereikend beheerssysteem van toepassing moest zijn. Een en ander werd ook als zodanig door de directie verklaard. Over de reikwijdte en diepgang van deze in-control statement bestond veel onduidelijkheid (Sampers, 2005). De oude Code kende weinig concrete aanwijzingen bij de inhoud van de in-control statement. Frijns en Poesiat (2006) concludeerden dan ook dat best practice-bepaling II.1.4 veelvuldig niet werd toegepast en dat veel vennootschappen en beleggersorganisaties hadden aangegeven meer behoefte te hebben aan aanwijzingen op dit punt.

Ten aanzien van de voornaamste risico's neemt de directie volgens de herziene Code in het directieverslag een beschrijving op van (best practice-bepaling II.1.4 Code):

- de voornaamste risico's gerelateerd aan de strategie;

- de opzet en werking van de interne risicobeheersings- en controlesystemen met betrekking tot de voornaamste risico's in het boekjaar;

- eventuele tekortkomingen in de interne risicobeheersings- en controlesystemen, eventuele significante wijzigingen, welke verbeteringen zijn gepland en dat één en ander met de auditcommissie van de raad van commissarissen is besproken.

Slechts ten aanzien van financiële verslaggevingrisico's (en niet van alle andere risico's) verklaart de directie volgens de herziene Code in het directieverslag met behulp van de incontrol statement dat de interne risicobeheersings- en controlesystemen een redelijke mate van zekerheid geven dat de financiële verslaggeving geen onjuistheden van materieel belang bevat en dat de risicobeheersings- en controlesystemen in het verslagjaar naar behoren hebben gewerkt. Tevens beveelt de Code aan om hiervan een duidelijke onderbouwing te geven. De herziene Code vereist in best practicebepaling III.1.5 dus geen mededeling over de werking van de interne beheersing in het lopende jaar.

De Code licht de begrippen 'redelijke mate van zekerheid', 'duidelijke onderbouwing' en 'materieel belang' niet nader toe. Het ligt hierbij voor de hand om voor de begrippen redelijke mate van zekerheid en materieel belang aansluiting te zoeken bij de begrippen zoals gehanteerd door het accountantsberoep. Van Leeuwen en Wallage (2010) stellen dat de Code het begrip 'duidelijke onderbouwing' niet nader uitwerkt en dat in de theorie nauwelijks methoden en instrumenten aanwezig zijn om de beoordeling uit te voeren. De Code licht niet toe hoe een dergelijke evaluatie uitgevoerd dient te worden; tevens wordt het belang van de interne beheersing niet expliciet genoemd. In de toelichting van de Code wordt wel aanbevolen om aan te geven welk raamwerk of normenkader is gehanteerd. De Groot en Koolstra (2006) zijn van mening dat het ontbreken van een referentiekader, naast onduidelijkheid ten aanzien van de benodigde breedte en diepgang van de beoordeling van de interne beheersing, de belangrijkste tekortkoming is.

Tot slot wordt opgemerkt dat de Code al best practice-bepaling I.1 bevat, die stelt dat ondernemingen een afzonderlijk corporate governance-hoofdstuk in het directieverslag dienen op te nemen met de hoofdlijnen van de corporate governance-structuur. Deze hoofdlijnen zijn echter niet nader uitgewerkt in de oude en de herziene Code. Het Besluit dat behandeld is in paragraaf 2.2 kan worden beschouwd als een uitwerking van die hoofdlijnen van de corporate governance-structuur, die reeds werden vereist in de Code. Het enige verschil is dat de door het Besluit vereiste informatie een wettelijk verplichte status heeft gekregen, in tegenstelling tot de 'pas toe of leg uit'-status van de Code.

\section{$2.4 \mathrm{Wft}$}

Ook in artikel 5:25 c van de Wft is een verklaring van de directie en eventuele andere verantwoordelijke personen opgenomen, namelijk de bestuursverklaring. In de bestuursverklaring die is ingevoerd als gevolg van het implementeren van de Europese Transparantie Richtlijn (2004/109/EC), verklaren de bij de uitgevende instelling verantwoordelijke personen met duidelijke vermelding van toenaam en functie, voor zover hun bekend:

- dat de jaarrekening een getrouw beeld geeft van de activa, de passiva, de financiële positie en de winst of het verlies van de uitgevende instelling en de gezamenlijk in de consolidatie opgenomen ondernemingen;

- en dat het jaarverslag een getrouw beeld geeft omtrent de toestand op de balansdatum, de gang van zaken gedurende het boekjaar van de uitgevende instelling en van de met haar verbonden ondernemingen waarvan de gegevens in haar jaarrekening zijn opgenomen en dat in het jaarverslag de wezenlijke risico's waarmee de uitgevende instelling wordt geconfronteerd, zijn beschreven. ${ }^{3}$

De bestuursverklaring is een document dat afzonderlijk gedeponeerd dient te worden en dat geen deel uitmaakt van het directieverslag of de jaarrekening. Hoewel de bestuursverklaring separaat gepubliceerd kan worden, is het aan te bevelen om de bestuursverklaring op te nemen in het jaarrapport. Volgens de Raad voor de Jaarverslaggeving wordt 
vrij algemeen aangenomen dat de bestuursverklaring slechts door de statutaire bestuurders ondertekend dient te worden en is het gangbaar om de verklaring als onderdeel van het directieverslag op te nemen (RJ Uiting 2009-9; RJ 400.207). Het opnemen als onderdeel van het directieverslag is overigens wel tegenstrijdig met de Wft, waarin wordt vereist dat de verklaring als een afzonderlijk stuk gepresenteerd wordt.

\subsection{Terminologie}

De term 'verklaring' wordt meerduidig gebruikt: naast de Bestuursverklaring en de in-control statement noemden wij al de corporate governance-verklaring. In dit laatste geval betwijfelen wij of er terecht wordt gesproken van een verklaring. Kijkend naar de aard van de vereiste informatie betreft het veel meer een opsomming van diverse aspecten van de corporate governance-inrichting dan dat het een formele verklaring zou zijn waarin het management een standpunt inneemt. Wij vermoeden dat hier een onjuiste vertaling van de Corporate Governance Richtlijn heeft plaatsgevonden. De Engelse versie van de Corporate Governance Richtlijn spreekt van 'corporate governance statement'. Het Engelse begrip 'statement' heeft naast de betekenis 'verklaring' ook de betekenis 'uiteenzetting', hetgeen ons inziens meer aansluit op het vereiste in het Besluit.

Daarnaast valt op dat de Wft op een aantal punten afwijkt van de Transparantie Richtlijn (zie tabel 1). De Engelstalige versie van de Transparantie Richtlijn spreekt van een 'true and fair view' overeenkomstig de toepasselijke reeks standaarden voor jaarrekeningen en een 'fair review' ten aanzien van het directieverslag. De Nederlandstalige versie van de Transparantie Richtlijn spreekt respectievelijk van een 'juist en getrouw beeld' en een 'getrouw overzicht'. Echter, de Wft hanteert andere begrippen. Met name het begrip getrouw beeld ten aanzien van het directieverslag gaat verder dan een 'fair review' of 'getrouw overzicht' (waarbij wij hier overigens doelen op de gangbare betekenis van deze termen in de accountancykringen en voorbijgaan aan de taalkundige betekenis van 'review'). Het hanteren van afwijkende begrippen in de Wft kan bij de vennootschappen tot verwarring leiden (Van Beurden en De Bos, 2009). Door Van Beurden en De Bos (2009) wordt voorgesteld om te verklaren dat het jaarverslag een eerlijke of redelijke beschrijving geeft. De Wft geeft voor het begrip 'getrouw beeld' overigens geen nadere definitie.

In het navolgende zullen wij concluderen dat deze taalkundige onduidelijkheden bij de vennootschappen tot verwarring en uiteenlopende oplossingen hebben geleid.

\subsection{Samenvatting}

De wijzigingen in de wet- en regelgeving hebben samenvattend geresulteerd in de volgende verklaringen op het gebied van corporate governance:

- corporate governance-verklaring voortvloeiend uit het Besluit met hierin wettelijke vereisten ten aanzien van informatieverstrekking op het gebied van corporate governance;

- in-control statement voortkomend uit de Code, waarin de directie verklaart in control te zijn ten aanzien van financiële verslaggevingsrisico's;

- bestuursverklaring als gevolg van het implementeren van de Europese Corporate Governance Richtlijn in de Wft, waarin de verantwoordelijke personen een verklaring opnemen met betrekking tot het getrouwe beeld van de jaarrekening en het jaarverslag.

\section{Empirisch onderzoek}

De populatie van ons onderzoek bestaat uit de jaarrapporten over boekjaar 2009 van de vennootschappen met een notering aan de AEX en AMX. De vennootschappen die statutair niet in Nederland gevestigd zijn, zijn uitgezonderd van het onderzoek aangezien deze buiten de reikwijdte van de Code vallen. De populatie bestaat derhalve uit 44 vennootschappen waarvan 21 deel uitmaken van de AEX en 23 van de AMX (voor de volledige lijst zie bijlage 3). De directieverslagen zijn veelal niet als zodanig aangeduid of herkenbaar gemaakt door betiteling en vermelding op de inhoudsopgave. Daarnaast is de ondertekening door de directie niet altijd aanwezig. Hoewel het gebruikelijk is dat het directieverslag door de directie als geheel of door de

Tabel 1 Vergelijking van Engelstalige Transparantie Richtlijn, Nederlandstalige Transparantie Richtlijn en de Wft

\begin{tabular}{|l|l|l|l|}
\hline Onderdeel verklaring & $\begin{array}{l}\text { Transparantie Richtlijn } \\
\text { (Engels) }\end{array}$ & $\begin{array}{l}\text { Transparantie Richtlijn } \\
\text { (Nederlands) }\end{array}$ & Artikel 5:25 c Wft \\
\hline $\begin{array}{l}\text { De activa, de passiva, de financiële positie en de winst of } \\
\text { het verlies volgens de jaarrekening }\end{array}$ & True and fair view & Juist en getrouw beeld & Getrouw beeld \\
\hline $\begin{array}{l}\text { Toestand op de balansdatum, de gang van zaken } \\
\text { gedurende het boekjaar en beschrijving van de wezenlijke } \\
\text { risico's volgens het directieverslag }\end{array}$ & Fair review & Getrouw overzicht & Getrouw beeld \\
\hline
\end{tabular}




\section{Tabel 2 Verschijningsvormen van de verklaring inzake corporate governance}

\begin{tabular}{|l|c|c|}
\hline Verschijningsvorm & Aantal & Percentage \\
\hline Opname in directieverslag & 7 & $16 \%$ \\
\hline $\begin{array}{l}\text { Geplaatst in jaarrapport buiten } \\
\text { directieverslag }\end{array}$ & 13 & $30 \%$ \\
\hline Verwijzing naar de website & 9 & $20 \%$ \\
\hline Totaal expliciete verklaringen & 29 & $66 \%$ \\
\hline $\begin{array}{l}\text { Geen expliciete corporate } \\
\text { governance-verklaring opgenomen }\end{array}$ & 15 & $34 \%$ \\
\hline Totaal & 44 & $100 \%$ \\
\hline
\end{tabular}

afzonderlijke directieleden wordt ondertekend, wordt dit niet door de wet geëist, in tegenstelling tot het ondertekenen van de jaarrekening.

Indien niet duidelijk uit het jaarrapport blijkt waaruit het directieverslag bestaat, hebben we op basis van de inhoudsopgave, lay-out en eventuele ondertekening zelf geïnterpreteerd welke passages tot het directieverslag behoren. In het navolgende gaan we achtereenvolgens in op de wijzigingen als gevolg van het Besluit, de Code en de Wft.

\subsection{Besluit}

Volgens het Besluit kan de vennootschap de corporate governance-verklaring uitbrengen als onderdeel van het directieverslag, als bijlage of op de website plaatsen. Uit tabel 2 en 3 blijkt dat 29 ondernemingen een expliciete verklaring hebben opgenomen en op welke wijze zij dit doen. Er is geen onderzoek gedaan naar het deponeren van separate corporate governance-verklaringen. Als expliciete corporate governance-verklaring hebben wij passages aangemerkt waarbij uit de titel of tekst blijkt dat deze als zodanig is bedoeld. Een best practice van deze wijze van invulling van het Besluit is Vopak (zie figuur 1).

Onderzoek naar de plaats van de 29 expliciete verklaringen in het jaarrapport toont een divers beeld, zoals blijkt uit tabel 3 . Meestal maakt de verklaring deel uit van het corporate governance-hoofdstuk. Negen keer blijkt uit de titel, of uit de inleidende tekst, dat het hoofdstuk dienst doet zowel als corporate governance-hoofdstuk zoals bedoeld in de Code, alsook als verklaring zoals bedoeld in het Besluit (zie bijvoorbeeld figuur 2: ING). Negen maal is in het hoofdstuk een afzonderlijke passage opgenomen met betrekking tot de verklaring inzake corporate governance. Opvallend is dat in één geval op twee verschillende plaatsen informatie is opgenomen over corporate governance: namelijk een afzonderlijk corporate governance-hoofdstuk en een afzonderlijke verklaring inzake corporate governance.

\section{Tabel 3 Plaats van de expliciete verklaring inzake corporate governance}

\begin{tabular}{|l|c|c|}
\hline Plaats & Aantal & Percentage \\
\hline $\begin{array}{l}\text { Gelijkgesteld aan corporate } \\
\text { governance-hoofdstuk }\end{array}$ & 9 & $31 \%$ \\
\hline $\begin{array}{l}\text { Opgenomen in corporate } \\
\text { governance-hoofdstuk }\end{array}$ & 9 & $31 \%$ \\
\hline $\begin{array}{l}\text { Expliciete verklaring in directieverslag } \\
\text { of overige informatie }\end{array}$ & 2 & $6 \%$ \\
\hline Geplaatst op de website & 9 & $31 \%$ \\
\hline Totaal & 29 & $100 \%$ \\
\hline
\end{tabular}

In de situaties dat de verklaring op de website is opgenomen, bevat het jaarrapport in alle gevallen een verwijzing naar de website. Een best practice van deze methode is AEGON (zie figuur 3). In acht gevallen is de verwijzing opgenomen in het corporate governance-hoofdstuk, in één geval in de risicoparagraaf. In de negen gevallen waar wordt verwezen naar de website, hebben wij onderzocht of de verklaring daadwerkelijk als document is opgenomen in de corporate governance-sectie. Bij acht ondernemingen is daadwerkelijk een expliciete verklaring aangetroffen op de website. In één geval ontbreekt de corporate governance-verklaring op de website. ${ }^{4}$

Aangezien er sprake is van 29 expliciete verklaringen, zijn wij nagegaan of ondernemingen ook een corporate governance-hoofdstuk hebben opgenomen. Alle ondernemingen hebben een corporate governance-hoofdstuk opgenomen; dertien maal is dit een losstaand hoofdstuk en bij 31 jaarrapporten maakt het corporate governance-hoofdstuk deel uit van het directieverslag.

Zoals blijkt uit tabel 4 kiezen vennootschappen meestal voor het geheel (38\%) of gedeeltelijk (34\%) opbouwen van de corporate governance-verklaring uit verwijzingen. Wij hebben verwijzingen aangetroffen naar het corporate governancehoofdstuk, de risicoparagraaf, het verslag van de raad van commissarissen, (andere delen van) de website, het directieverslag en de toelichting op de jaarrekening. Ook vier van de acht verklaringen die op de website zijn geplaatst, bestaan geheel of gedeeltelijk uit verwijzingen naar andere delen van de website of naar delen van het jaarrapport.

Samenvattend kan worden gesteld dat in alle gevallen een corporate governance-hoofdstuk opgenomen is als gevolg van de Code. Een expliciete corporate governance-verklaring hebben wij niet bij alle ondernemingen aangetroffen. De verklaringen die wij hebben angetroffen, maken veelal gebruik van verwijzingen, wat de leesbaarheid en de toegevoegde waarde voor de gebruiker van het jaarrapport niet 


\section{Figuur 1 Expliciete corporate governance-verklaring Vopak}

\begin{tabular}{|c|c|}
\hline Corporate Governance Verslag & $\begin{array}{l}\text { niet later dan op dertigste dag voor die van de vergadering heeft ontvangen en mits geen } \\
\text { zwaarwichtig belang van Vopak zich daartegen verzet. }\end{array}$ \\
\hline \multicolumn{2}{|l|}{ Inleiding } \\
\hline $\begin{array}{l}\text { Dit verslag is opgenomen uit hoofde van artikel 2a van het Besluit van } 23 \text { december } 2004 \\
\text { tot vaststelling van nadere voorschriften omtrent de inhoud van het jaarverslag (hierna het } \\
\text { 'Besluit') en bevat de mededelingen als bedoeld in de artikelen 2, 3a en 3b van het } \\
\text { Besluit. Voor zover in dit verslag wordt verwezen naar de relevante vindplaatsen in dit } \\
\text { jaarverslag, dienen de alsdaar opgenomen mededelingen als hier ingelast en herhaald te } \\
\text { worden beschouwd. }\end{array}$ & $\begin{array}{l}\text { Op Algemene Vergaderingen van Aandeelhouders kunnen besluiten worden genomen met } \\
\text { een volstrekte meerderheid van de uitgebrachte stemmen, tenzij de statuten van Vopak of } \\
\text { de wet een grotere meerderheid voorschrijven. } \\
\text { De belangrijkste bevoegdheden van de Algemene Vergadering van Aandeelhouders zijn: } \\
\text { - vaststelling jaarrekening; } \\
\text { - goedkeuring dividendvoorstel; } \\
\text { - verlening van decharge aan leden van de Raad van Bestuur; }\end{array}$ \\
\hline Naleving van de Nederlandse Corporate Governance Code & • verlening van decharge aan leden van de Raad van Commissarissen; \\
\hline Vopak leeft de Nederlandse Corporate Governance Code (de 'Code') na. De tekst van de & • vaststelling remuneratiebeleid voor de leden van de Raad van Bestuur; \\
\hline Code is te downloaden via www.commissiecorporategovernance.nl. & • vaststelling van de remuneratie van de leden van de Raad van Commissarissen; \\
\hline $\begin{array}{l}\text { Voor de mededeling omtrent de naleving van de principes en bestpracticebepalingen van } \\
\text { de Code voor zover deze zijn gericht tot de Raad van Bestuur of de Raad van } \\
\text { Commissarissen zie pagina } 67 \text { 'Corporate Goverance'. }\end{array}$ & $\begin{array}{l}\text { - benoeming, schorsing en ontslag van de leden van de Raad van Bestuur; } \\
\text { - benoeming schorsing en ontslag van de leden van de Raad van Commissarissen; } \\
\text { - benoeming registeraccountant; } \\
\text { - machtiging van de Raad van Bestuur tot inkoop eigen aandelen; }\end{array}$ \\
\hline Beheers- en controlesysteem & • uitgifte van aandelen en verlening van rechten tot het nemen van aandelen \\
\hline $\begin{array}{l}\text { Voor de mededeling omtrent de belangrijkste kemmerken van de beheers- en } \\
\text { controlesystemen van Koninklijke Vopak N.V. ('Vopak') en van de groep waarvan de } \\
\text { financiële gegevens in haar jaarrekening zijn opgenomen zie pagina } 56 \text { tot en met } 60 \\
\text { 'Risico's en risicobeheersing'. }\end{array}$ & $\begin{array}{l}\text { (optierechten) respectievelijk tot aanwijzing van de Raad van Bestuur om gedurende } \\
\text { een periode daartoe te mogen besluiten; } \\
\text { - uitsluiting of beperking van het voorkeursrecht van aandeelhouders bij uitgifte van aandelen } \\
\text { en verlening van rechten tot het nemen van aandelen respectievelijk tot aanwijzing van de } \\
\text { Raad van Bestuur om gedurende een periode daartoe te mogen besluiten; }\end{array}$ \\
\hline De aandeelhoudersvergadering & - goedkeuring van besluiten van de Raad van Bestuur betreffende een belangrijke \\
\hline Aandeelhouders van Vopak oefenen hun rechten uit tijdens de jaarlijkse en buitengewone & wijziging in de identiteit of het karakter van Vopak of haar onderneming; en \\
\hline $\begin{array}{l}\text { Algemene Vergadering van Aandeelhouders. } \\
\text { De jaarlijkse Algemene Vergadering van Aandeelhouders dient uiterlijk op } 30 \text { juni te } \\
\text { worden gehouden. Op de agenda van deze vergadering dienen bepaalde onderwerpen te }\end{array}$ & $\begin{array}{l}\text { - besluiten tot wijziging van de statuten, ontbinding, juridische fusie of splitsing van } \\
\text { Vopak. }\end{array}$ \\
\hline staan zoals omschreven in de statuten van Vopak of opgenomen in de wet, waaronder de & Samenstelling en functioneren van de Raad van Bestuur \\
\hline $\begin{array}{l}\text { vaststelling van de jaarrekening. Buitengewone algemene vergaderingen van } \\
\text { aandeelhouders worden gehouden op verzoek van de Raad van Bestuur, de Raad van }\end{array}$ & Voor de samenstelling van de Raad van Bestuur wordt verwezen naar pagina 158. \\
\hline $\begin{array}{l}\text { Commissarissen of één of meer aandeelhouders en certificaathouders die alleen of } \\
\text { gezamenlijk ten minste een tiende gedeelte van het geplaatste kapitaal vertegenwoordigen. }\end{array}$ & $\begin{array}{l}\text { De leden van de Raad van Bestuur zijn collectief verantwoordelijk voor het besturen van } \\
\text { Vopak, de algemene gang van zaken van de onderneming van Vopak alsmede de gang van } \\
\text { zaken binnen de met Vopak verbonden groepsvennootschappen. Daarbij streven zij naar }\end{array}$ \\
\hline $\begin{array}{l}\text { Een onderwerp, waarvan de behandeling schriftelijk is verzocht door één of meer } \\
\text { aandeelhouders en certificaathouders die alleen of gezamenlijk ten minste een honderdste }\end{array}$ & het creëren van aandeelhouderswaarde op de lange termijn. \\
\hline $\begin{array}{l}\text { gedeelte van het geplaatste kapitaal vertegenwoordigen of waarvan de aandelen en/of } \\
\text { certificaten ten minste een waarde vertegenwoordigen van EUR } 50 \text { miljoen, wordt } \\
\text { opgenomen in de oproeping of op dezelfde wijze aangekondigd indien Vopak het verzoek }\end{array}$ & $\begin{array}{l}\text { Voor een meer gedetailleerde beschrijving van het functioneren van de Raad van Bestuur } \\
\text { wordt verwezen naar het reglement van de Raad van Bestuur dat is geplaatst op de } \\
\text { website van Vopak (www.vopak.com) in het corporate goverance gedeelte. }\end{array}$ \\
\hline
\end{tabular}

ten goede komt. Wij zijn voorstander van het zo veel mogelijk concentreren van corporate governance-informatie op één plaats. Hiervoor lijkt het corporate governance-hoofdstuk de meest logische plaats.

\subsection{Code}

Naast de vereiste algemene beschrijving van de risico's bestond, zoals vermeld, op basis van de oorspronkelijke tekst in de Code onduidelijkheid over de reikwijdte en diepgang van de in-control statement. In de herziene Code wordt dit verduidelijkt. Er wordt namelijk alleen een in-control statement gevraagd met betrekking tot de financiële verslaggevingsrisico's. Wij hebben bij alle onderzochte ondernemingen een in-control statement aangetroffen. ${ }^{5}$ Deze maakt in 27 gevallen deel uit van het directieverslag en is 17 maal buiten het directieverslag geplaatst.

In tabel 5 is opgenomen op welke plaats in het jaarrapport de in-control statement is opgenomen. In ongeveer de helft van de jaarrapporten is de in-control statement in de 
Figuur 2 Gelijkstelling corporate governance-hoofdstuk en verklaring door ING

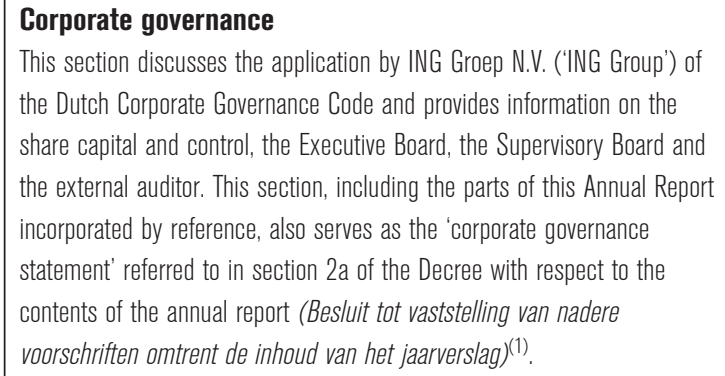

risicoparagraaf opgenomen. Aangezien de in-control statement betrekking heeft op verslaggevingsrisico's is dit een logische plaats, ook temeer het de verantwoordelijkheid van de directie betreft. Daarnaast hebben wij echter ook verklaringen aangetroffen in het corporate governancehoofdstuk, als onderdeel van het directieverslag, als een losstaande verklaring, in een afzonderlijk hoofdstuk met bestuursverklaringen en in de jaarrekening.

Vervolgens hebben wij de in-control statement vergeleken met de tekst zoals voorgeschreven in de Code. Tevens hebben wij afwijkende passages beoordeeld. De voorgeschreven passage maakt in 38 gevallen (86\%) deel uit van de in-control statement.

In vijf gevallen is een in-control statement opgenomen die is gebaseerd op de Amerikaanse Sarbanes Oxley-wetgeving. Hierin wordt alleen een uitspraak gevraagd van de CEO en CFO met betrekking tot de werking van de interne risicobeheersings- en controlesystemen. ${ }^{6}$

Wij hebben ook beoordeeld in hoeverre de verklaringen afwijken van best practice-bepaling II.I.5. In twee verklaringen wordt in plaats van een opmerking dat de financiële verslaggeving geen onjuistheden van materieel belang bevat, gesproken over onjuistheden van wezenlijk belang. In accountancyterminologie is 'wezenlijk' een ruimer begrip dan 'materieel'. Indien de directie verwijst naar 'wezenlijk', dan gaat de in-control statement minder ver dan de vereiste verklaring in de Code, aangezien er een kans bestaat dat er dan wel materiële, maar geen wezenlijke fouten aanwezig zijn.

Een aantal verklaringen gaat juist verder dan de Code. Als voorbeeld: de directie van TNT verklaart dat de interne risicobeheersings- en controlesystemen een redelijke mate van zekerheid geven en dat de jaarrekening vrij is van materiële onjuistheden (zie figuur 4). Een ander voorbeeld is de directie van BinckBank, die toevoegt dat een redelijke
Figuur 3 Verwijzing naar de website in jaarrapport AEGON

\section{Corporate Governance Statement}

Generally, AEGON applies the best practice provisions set out in the Code. For an extensive review of AEGON's compliance with the Code, please refer to the 'Corporate Goverance Statement' on AEGON's corporate website (www.aegon. com). A detailed explanation is given below for those instances where AEGON does not fully apply the best practice provisions of the Code. In these few instances, AEGON adheres, as far as possible, to the spirit of the Code.

\section{Tabel 4 Opbouw van de verklaring inzake corporate governance}

\begin{tabular}{|l|c|c|}
\hline Opbouw & Aantal & Percentage \\
\hline $\begin{array}{l}\text { Verklaring is geheel opgebouwd uit } \\
\text { verwijzingen }\end{array}$ & 11 & $38 \%$ \\
\hline $\begin{array}{l}\text { Verklaring is gedeeltelijk opgebouwd } \\
\text { uit verwijzingen }\end{array}$ & 10 & $34 \%$ \\
\hline De verklaring is een zelfstandig stuk & 7 & $24 \%$ \\
\hline $\begin{array}{l}\text { De verklaring is niet aanwezig in } \\
\text { corporate governance-sectie op website }\end{array}$ & 1 & $3 \%$ \\
\hline Totaal & 29 & $100 \%$ \\
\hline
\end{tabular}

\section{Tabel 5 Plaats van de in-control statement}

\begin{tabular}{|l|c|c|}
\hline Plaats & Aantal & Percentage \\
\hline Risicoparagraaf & 22 & $50 \%$ \\
\hline Corporate governance-hoofdstuk & 9 & $20 \%$ \\
\hline $\begin{array}{l}\text { Onderdeel directieverslag afgezonderd } \\
\text { van risicoparagraaf of corporate } \\
\text { governance-hoofdstuk }\end{array}$ & 6 & $14 \%$ \\
\hline $\begin{array}{l}\text { Afzonderlijk hoofdstuk } \\
\text { 'Bestuursverklaringen' }\end{array}$ & 4 & $9 \%$ \\
\hline Zelfstandige in-control statement & 2 & $5 \%$ \\
\hline Onderdeel van de jaarrekening & 1 & $2 \%$ \\
\hline Totaal & 44 & $100 \%$ \\
\hline
\end{tabular}

mate van zekerheid wordt verkregen, dat de directie op de hoogte is van de mate waarin doelstellingen worden gerealiseerd en dat de vennootschap zich houdt aan de van toepassing zijnde wet- en regelgeving (zie figuur 5). Ten slotte verklaart één directie dat de jaarrekening een getrouw beeld geeft van de financiële positie en van de resultaten en dat de juiste toelichtingen zijn gegeven. Dit beschouwen wij als een element dat meer op zijn plaats is in de bestuursverklaring, die verderop wordt behandeld. 
Daarnaast dienen de directies ten aanzien van financiële verslaggevingsrisico's te verklaren dat de risicobeheersings- en controlesystemen in het verslagjaar naar behoren hebben gewerkt. Dit element is in alle jaarrapporten opgenomen. Bij 41 ondernemingen betreft dit een positieve formulering, vergelijkbaar met de tekst gehanteerd in de Code, en bij drie ondernemingen een negatieve formulering. Een negatieve formulering is een passage met een dubbele ontkenning, in de trant van 'wij hebben geen indicaties dat de risicobeheersings- en controlesystemen in 2009 niet naar behoren hebben gewerkt'.

Hoewel de Code in best practice-bepaling II.1.5 alleen een in-control statement vraagt ten aanzien van het verslagjaar, doen zestien directies in de in-control statement een uitspraak over de werking van risicobeheersings- en controlesystemen in het lopende jaar. Hoewel deze informatie wel wordt vereist als onderdeel van de risicobeschrijving (best practice-bepaling II.1.4), hoeft zij niet te worden opgenomen als onderdeel van de in-control statement. Een andere toevoeging die wij in 30 rapporten hebben aangetroffen, is de vermelding dat de systemen weliswaar een redelijke, maar geen absolute zekerheid geven. Eén directie spreekt van 'reasonably effective', wat een minder sterke uitspraak is dan 'naar behoren'.

De Code vereist een duidelijke onderbouwing van de incontrol statement. Wij hebben onderzocht of in de passage met de in-control statement een onderbouwing is opgenomen. Aangezien 'duidelijk' niet nader is toegelicht in de Code, geven wij geen waardeoordeel aan de gegeven onderbouwing. Bij 38 in-control statements is een onderbouwing gegeven, waarbij in een vijftal gevallen wordt volstaan met een verwijzing naar de risicoparagraaf. De onderbouwing die wij meerdere malen hebben aangetroffen, bestaat uit: uitvoeren van risicoanalyse, ('review' van de) beoordeling van de werking van risicobeheersings- en controlesystemen, bespreking van de uitkomsten met de raad van commissarissen, auditcommissie en/of externe accountant en gebruik van interne in-control statements van het hoger management. Een voorbeeld van een onderneming die een duidelijke onderbouwing geeft, is Heineken (zie figuur 6). Acht ondernemingen maken in de onderbouwing melding van een raamwerk, in alle gevallen COSO. Een voorbeeld van een onderneming die naar $\mathrm{COSO}$ verwijst, is Philips (zie figuur 7).

\subsection{Wft}

De laatste verklaring waarop de jaarrapporten zijn onderzocht, is de bestuursverklaring. Alle onderzochte jaarrapporten bevatten een bestuursverklaring. De verklaring maakt 26 keer deel uit van het directieverslag en is achttien keer buiten het directieverslag opgenomen. Hoewel het verdedigbaar is om de bestuursverklaring op te nemen als

\section{Figuur 4 Aangepaste in-control statement TNT}

The Board of Management believes to the best of its knowledge based on the outcome of TNTspecific approach to risk management, internal control, integrity and compliance as outlined above, that TNT's risk management and internal control over financial reporting have worked effectively over the year ended 31 December 2009 and provide a reasonable assurance that the financial reporting is free from material inaccuracies or misstatement.

Figuur 5 Aangepaste in-control statement Binckbank

In overeenstemming met de best practice bepalingen zoals bedoeld in de Corporate Goverance Code, en met inachtneming van de hierna genoemde beperkingen, bevestigen wij dat onze risicobeheersings- en controlesystemen een redelijke mate van zekerheid verschaffen dat wij op de hoogte zijn van a) de mate waarin de strategische en operationele doelstellingen van BinckBank worden gerealiseerd, b) dat BinckBank zich houdt aan de van toepassing zijnde wet- en regelgeving en c) onze financiële verslaggeving geen materiële onjuistheden bevat. Voorts verklaren wij dat deze risicobeheersing- en controlesystemen gedurende 2009 naar behoren hebben gefunctioneerd.

\section{Figuur 6 Duidelijke onderbouwing bij in-control statement van Heineken}

\section{Financial reporting}

The risk management and control systems over financial reporting contain clear accounting policies, a standard chart of accounts and Assurance Letters signed by regional and local management. The Heineken common systems and embedded control frameworks that have been implemented in a large number of the Operating Companies support common accounting and regular financial reporting in standard forms. Testing of the key controls relevant for financial reporting is part of the common Internal Audit Approach.

The worldwide external audit activities provide additional assurance on true and fair presentation of the financial reporting at the Operating Company level. Within the scope of the external auditors' financial audit assignment, they also report on internal control issues through their management letters, and they attend the regional and certain local assurance meetings.

In 2009, special attention was given to the continuous integration of financial reporting of the acquired business from former Scottish \& Newcastle and other acquisitions, including transfer to the Heineken Accounting Policies. Almost all acquired companies have already implemented the Heineken standard chart of accounts.

\section{Figuur 7 Vermelding raamwerk bij in-control statement door Philips}

The Board of Management conducted an assessment of the Company's internal control over financial reporting based on the "Internal Control-Integrated Framework" established by the Committee of Sponsoring Organizations of the Treadway Commission (COSO). Based on that assessment, the Board of Management concluded that, as of December 31, 2009, the Company's internal control over Group financial reporting is considered effective. 
Tabel 6 Plaats van de bestuursverklaring

\begin{tabular}{|l|r|c|}
\hline Plaats & Aantal & Percentage \\
\hline Expliciete verklaring & 5 & $11 \%$ \\
\hline $\begin{array}{l}\text { Directieverslag (niet onderdeel risicoparagraaf } \\
\text { of corporate governance-hoofdstuk) }\end{array}$ & 14 & $32 \%$ \\
\hline Corporate governance-hoofdstuk & 10 & $23 \%$ \\
\hline Risicoparagraaf & 8 & $18 \%$ \\
\hline Afzonderlijk hoofdstuk 'Bestuursverklaringen' & 4 & $9 \%$ \\
\hline Jaarrekening & 2 & $5 \%$ \\
\hline Overige gegevens & 1 & $2 \%$ \\
\hline Totaal & 44 & $100 \%$ \\
\hline
\end{tabular}

onderdeel van het directieverslag aangezien de directie zich het meest kwalificeert bij de uitgevende instelling als ter zake verantwoordelijk, is dit niet in lijn met de Wft. Zoals eerder beschreven is de bestuursverklaring door de wetgever bedoeld als een afzonderlijk document, dat ook afzonderlijk gedeponeerd dient te worden.

In vijf jaarrapporten is de bestuursverklaring opgenomen als een geheel losstaande, expliciete verklaring (zie tabel 6). De bestuursverklaring wordt in de meeste gevallen opgenomen als onderdeel van het directieverslag (al dan niet als onderdeel van de risicoparagraaf of het corporate governance-hoofdstuk). In de overige situaties is de verklaring geplaatst als onderdeel van de risicoparagraaf of het corporate governance-hoofdstuk buiten het directieverslag, in een afzonderlijk hoofdstuk 'bestuursverklaringen', in de jaarrekening of in de overige gegevens van de jaarrekening.

De Wft vereist dat de bestuursverklaring ondertekend wordt door bij de uitgevende instelling ter zake verantwoordelijke personen met duidelijke vermelding van toenaam en functie. De meeste vennootschappen wijzen de directie aan als het verantwoordelijk orgaan. Slechts één onderneming, namelijk Eurocommercial Properties, laat de raad van commissarissen als verantwoordelijke personen meetekenen (zie figuur 8). Twaalf keer valt de ondertekening samen met de ondertekening van het directieverslag door het plaatsen van de bestuursverklaring aan het eind van het directieverslag, net voor de ondertekening.?

Bij vier vennootschappen ontbreekt de ondertekening in haar geheel, bij één onderneming tekenen alleen de CEO en CFO, terwijl de directie uit meer leden bestaat, twee maal ondertekent de directie als geheel en vijf keer is ondertekend met afzonderlijke namen, maar zonder vermelding van functies.

Verder hebben wij onderzocht of ondernemingen afwijken van de tekst zoals blijkt uit de Wft. Twaalf ondernemingen
Tabel 7 Ondertekening van de bestuursverklaring

\begin{tabular}{|l|c|c|}
\hline $\begin{array}{l}\text { Verantwoordelijke personen die de } \\
\text { bestuursverklaring ondertekenen }\end{array}$ & Aantal & Percentage \\
\hline Directie & 25 & $57 \%$ \\
\hline Directie zonder vermelding van functies & 5 & $11 \%$ \\
\hline Directie als geheel & 2 & $5 \%$ \\
\hline Directie en raad van commissarissen & 1 & $2 \%$ \\
\hline Deel van de directie & 1 & $2 \%$ \\
\hline Niet expliciet ondertekend door directie & 6 & $14 \%$ \\
\hline Niet ondertekend & 4 & $9 \%$ \\
\hline Totaal & 44 & $100 \%$ \\
\hline
\end{tabular}

Figuur 8 Bestuursverklaring Eurocommercial Properties

\section{Verklaring}

Met verwijzing naar de Europese Transparantie Richtlijn en de Wet op het financieel toezicht verklaren wij voor zover ons bekend, dat de jaarrekening voor het boekjaar geëindigd op 30 juni 2009 een getrouw beeld geeft van de bezittingen, schulden, financiële positie en de resultaten van de Groep en het jaarverslag van de directie een getrouw beeld geeft omtrent de gang van zaken gedurende het boekjaar en omtrent de toestand op de balansdatum van de Groep en daarin de wezenlijke risico's waarmee de Groep wordt geconfronteerd, zijn beschreven.

Amsterdam, 25 augustus 2009

Directie

J.P. Lewis, voorzitter W.G. van Hassel, voorzitter

E.J. van Garderen H.W. Bolland

P.W. Haasbroek

J.C. Pollock

A.E. Teeuw

vermelden in overeenstemming met de oorspronkelijke tekst uit de Transparantie Richtlijn dat de jaarrekening een 'getrouw beeld' geeft volgens de toepasselijke reeks standaarden voor jaarrekeningen, waarbij negen vennootschappen ook specifiek aangeven welk verslaggevingsstelsel van toepassing is.

Vijf ondernemingen nemen voor het directieverslag en jaarrekening verwijzingen op naar de desbetreffende bladzijden. Uit de beoordeling of deze verwijzingen overeenkomen met wat wij beschouwen als directieverslag, blijkt wederom dat onduidelijkheid bestaat over de reikwijdte van het directieverslag. Vier directies wijken in de bestuursverklaring af van de passages zoals bedoeld is in artikel 391 BW 2 als directieverslag. Andere toevoegingen die wij hebben aangetroffen, zijn het toevoegen dat de jaarrekening een getrouw beeld geeft ten aanzien van de kasstromen en het toevoegen van een inleidende passage ten aanzien van verantwoordelijkheden van de directie. 
Door het implementeren van de Transparantie Richtlijn in de Wft is onduidelijkheid ontstaan over de begripvorming. De begrippen 'true and fair view' en 'fair review' zijn vanuit het Engels vertaald als 'getrouw beeld'. Gezien de onduidelijkheid is het interessant om te onderzoeken hoe de begrippen vanuit het Nederlands terug worden vertaald naar het Engels. De mogelijkheid bestaat namelijk dat hoewel de directies hetzelfde bedoelen, zij als gevolg van de vertaling van tekst zoals opgenomen in de Wft afwijken. Zoals blijkt uit tabel 8 en 9 is er een consistent beeld ten aanzien van de jaarrekening; echter, de bewoordingen met betrekking tot het getrouw beeld van het directieverslag lopen uiteen. De meest voorkomende terminologie is 'true and fair view' en 'fair review'.

Geconcludeerd mag worden dat veelvuldig wordt afgeweken van het beschouwen van de bestuursverklaring als een afzonderlijk document zoals vereist door de Wft. Tevens bestaat onduidelijkheid over de te hanteren terminologie in het Engels en Nederlands. Ten slotte geschiedt de ondertekening niet altijd in overeenstemming met de Wft.

\subsection{Combinaties van verklaringen}

Interessant is ook om te onderzoeken of vennootschappen de verklaringen combineren of zelfs volledig integreren. Een combinatie is het plaatsen van twee of meer verklaringen in dezelfde afzonderlijke paragraaf of het integreren van twee of meer verklaringen, zodat het feitelijk om één verklaring gaat. Het is vanuit praktisch oogpunt verdedigbaar om alle verklaringen die van de directie worden geëist, onder te brengen op dezelfde plaats. Hierbij zij wel opgemerkt dat de corporate governance-verklaring niet 'echt' een verklaring is en dat een combinatie met de andere 'echte' verklaringen niet voor de hand ligt.

Wij beschrijven in deze paragraaf de combinatie in-control statement, bestuursverklaring en de verklaring inzake corporate governance. Het combineren van de corporate governance-verklaring en het corporate governance-hoofdstuk is eerder behandeld. Wederom blijkt uit ons onderzoek

\section{Tabel 8 Vertaling van 'getrouw beeld' ten aanzien van jaarrekening}

\begin{tabular}{|l|c|c|}
\hline $\begin{array}{l}\text { Vertaling van 'getrouw beeld' ten aanzien van } \\
\text { jaarrekening }\end{array}$ & Aantal & Percentage \\
\hline True and fair view & 40 & $91 \%$ \\
\hline True and fair picture & 1 & $2 \%$ \\
\hline True and fair reflection & 1 & $2 \%$ \\
\hline True and fair account & 1 & $2 \%$ \\
\hline True and fair representation & 1 & $2 \%$ \\
\hline Totaal & 44 & $100 \%$ \\
\hline
\end{tabular}

\section{Tabel 9 Vertaling van 'getrouw beeld' ten aanzien van directieverslag}

\begin{tabular}{|l|c|c|}
\hline $\begin{array}{l}\text { Vertaling van 'getrouw beeld' ten aanzien van } \\
\text { directieverslag }\end{array}$ & Aantal & Percentage \\
\hline True and fair view & 27 & $61 \%$ \\
\hline Fair review & 11 & $25 \%$ \\
\hline True and fair picture & 2 & $5 \%$ \\
\hline True and fair reflection & 1 & $2 \%$ \\
\hline True and fair account & 1 & $2 \%$ \\
\hline True and fair representation & 1 & $2 \%$ \\
\hline Fair view & 1 & $2 \%$ \\
\hline Totaal & 44 & $100 \%$ \\
\hline
\end{tabular}

een uiteenlopend beeld. In totaal hebben 22 ondernemingen een combinatie opgenomen van twee of drie verklaringen.

Zeventien ondernemingen combineren de in-control statement en de bestuursverklaring. Twee ondernemingen nemen de verschillende elementen uit de in-control statement en de bestuursverklaring op in één en dezelfde verklaring. Drie ondernemingen plaatsen de bestuursverklaring en corporate governance-verklaring in dezelfde, soms een afzonderlijke, paragraaf. Twee ondernemingen plaatsen alle drie de verklaringen in dezelfde paragraaf.

\section{Tabel 10 Combinaties van verklaringen}

\begin{tabular}{|c|c|c|c|}
\hline Verklaring & Aantal & Combinatievorm & Aantal \\
\hline \multirow[t]{2}{*}{ Gecombineerde in-control statement en bestuursverklaring } & 17 & Beide opgenomen in een afzonderlijke paragraaf & 15 \\
\hline & & Volledig geïntegreerd & 2 \\
\hline $\begin{array}{l}\text { Gecombineerde bestuursverklaring en verklaring inzake corporate } \\
\text { governance }\end{array}$ & 3 & Beide opgenomen in een afzonderlijke paragraaf & 3 \\
\hline \multirow[t]{2}{*}{$\begin{array}{l}\text { Gecombineerde in-control statement, bestuursverklaring en verklaring } \\
\text { inzake corporate governance }\end{array}$} & 2 & $\begin{array}{l}\text { Gecombineerde in-control statement en bestuursverklaring in corporate } \\
\text { governance-verklaring }\end{array}$ & 1 \\
\hline & & Drie verklaringen opgenomen in dezelfde afzonderlijke paragraaf & 1 \\
\hline Totaal aantal combinaties & 22 & Totaal aantal combinaties & 22 \\
\hline
\end{tabular}




\section{Conclusie}

Als gevolg van gewijzigde wet- en regelgeving dienen beursgenoteerde ondernemingen aanzienlijk meer corporate governance-informatie op te nemen. Opvallend is dat deze wet- en regelgeving in een aantal gevallen min of meer dezelfde informatie lijkt te vereisen. Niet is altijd duidelijk of het daadwerkelijk om dezelfde informatie gaat of dat bepaalde informatieverstrekking kan worden gecombineerd. Ook is niet altijd duidelijk op welke plaats bepaalde informatie dient te worden opgenomen. De belangrijkste bevindingen, eventueel gevolgd door een aanbeveling, zijn hierna weergegeven.

De belangrijkste bevindingen met betrekking tot de corporate governance-verklaring zijn:

- Negenentwintig ondernemingen nemen expliciet de vereiste informatie vanuit de corporate governanceverklaring op. Dit betekent mogelijk dat 15 ondernemingen van mening zijn dat zij reeds aan deze informatievereisten voldeden door middel van het opnemen van het corporate governance-hoofdstuk. Dit lijkt ons een verdedigbaar standpunt.

- Negen ondernemingen benutten de website om deze informatie te geven, hetgeen een relatief gering aantal is.

- De ondernemingen hebben de corporate governanceverklaring niet geïnterpreteerd als een verklaring, maar veel meer als een beschrijving van de belangrijkste aspecten van corporate governance.

Op basis van deze bevindingen is het wenselijk dat er meer consistentie komt in de informatieverstrekking. Het lijkt ons het meest voor de hand liggend dat het Besluit wordt gezien als een uitwerking van de hoofdlijnen van de corporate governance-structuur, die reeds werd vereist in de Code. Wij bevelen dan ook aan de gevraagde informatie uit het Besluit op te nemen in een corporate governance-hoofdstuk, dat onderdeel is van het directieverslag. Wij bevelen aan om het corporate governance-hoofdstuk voorts op de website te plaatsen. Indien blijkt dat dit betere communicatie is, kan overwogen worden om het corporate governance-hoofdstuk dat in het directieverslag is opgenomen, te laten vervallen.

De belangrijkste bevindingen met betrekking tot de incontrol statement zijn:

- De in-control statement is algemeen aanvaard, aangezien alle ondernemingen deze hebben opgenomen. De plaats waar deze in-control statement wordt opgenomen, is niet consistent, hoewel de meeste ondernemingen deze verklaring onderdeel laten zijn van de risicoparagraaf.

- De meeste ondernemingen geven een onderbouwing van de in-control statement. Uit ons onderzoek blijkt echter dat de onderbouwingen uiteenlopen.

- De belangrijkste bevindingen met betrekking tot de bestuursverklaring zijn:
- Alle onderzochte ondernemingen hebben een bestuursverklaring opgenomen in het jaarrapport. Met betrekking tot het getrouwe beeld van het directieverslag worden verschillende verklaringen gebruikt: een deel van de verantwoordelijke personen verklaart dat er sprake is van een getrouw beeld, terwijl een ander deel spreekt van een getrouw overzicht.

- In de praktijk blijken ondernemingen geneigd om de incontrol statement te combineren met de bestuursverklaring.

Het hanteren van afwijkende begrippen kan tot verwarring leiden. Wij stellen voor om te verklaren dat het jaarverslag een eerlijke of redelijke beschrijving geeft. Wij zijn geen voorstander van het combineren van de bestuursverklaring met de in-control statement, aangezien de wetgever de bestuursverklaring heeft bedoeld als een afzonderlijk juridisch document.

Op basis van deze uitkomsten concluderen wij dat de rapportage van corporate governance-informatie zeer uiteenloopt. Verdere harmonisatie op dit gebied lijkt gewenst. Wij bevelen ondernemingen aan om kritisch te kijken naar de overige informatie bij het directieverslag en na te gaan of deze informatie opgenomen kan worden in het directieverslag of gepubliceerd kan worden op de website. We zagen in ieder geval dat ten aanzien van de corporate governance-verklaring hier nog weinig gebruik van gemaakt wordt. Dit is overeenkomstig eerder onderzoek betreffende de verslaggeving door de raad van commissarissen in 2009 (Lückerath-Rovers, Scheltema en De Bos, 2010). Ook de wetgever zou hierbij kunnen helpen, door duidelijke criteria te ontwikkelen voor informatie die niet noodzakelijkerwijs in het jaarverslag wordt vermeld, doch wel algemeen verkrijgbaar gesteld dient te worden. Hiervoor is de website zeer geschikt.

Prof. dr. A. de Bos RA is parttime hoogleraar Bedrijfseconomie

aan de Erasmus Universiteit Faculteit der Rechtsgeleerdheid en

is als partner verbonden aan Ernst \& Young.

Drs. H.W. Edelman RA is als senior staff werkzaam bij Ernst \&

Young en verricht naast zijn werkzaamheden in de

controlepraktijk onderzoek op het gebied van corporate

governance.

Prof. dr. M. Lückerath-Rovers is hoogleraar Corporate

Governance aan Nyenrode Business Universiteit en tevens

verbonden aan de Erasmus Universiteit Rotterdam. Zij is

tevens commissaris bij ASN Bank Beleggingsfondsen NV en

redactielid van het Tijdschrift Goed Bestuur.

Drs. M.A. Scheltema is als Research Fellow verbonden aan de Erasmus Universiteit Rotterdam. Daarnaast is zij commissaris en toezichthouder bij een aantal vennootschappen. 


\section{Noten}

I. Op 20 maart 2009 is het Besluit van 23 december 2004 tot vaststelling van nadere voorschriften omtrent de inhoud van het jaarverslag aangepast, hetgeen op 10 december 2009 gepubliceerd is in de Staatscourant. 2 Gepubliceerd in de Staatscourant van 3 december 2009.

3. Wij interpreteren dat de Wft met jaarverslag doelt op het jaarverslag zoals uitgewerkt in artikel 391 BW 2 en door ons aangeduid als directieverslag.

4. Navraag bij de onderneming wijst uit dat de oorzaak ligt bij een fusie. De onderneming verwijst naar de corporate governance-verklaring van de onderneming waarmee zij fuseert.
5 Wij maken volledigheidshalve de opmerking dat één directie op twee plaatsen een in-control statement heeft gegeven: in zowel het directieverslag als het corporate governance-hoofdstuk. Voor het onderzoek hebben wij deze beschouwd als onderdeel van het corporate governance-hoofdstuk aangezien de verklaring op deze plaats het meest uitgebreid is behandeld.

6 In één geval is opgenomen dat de interne risicobeheersings- en controlesystemen een redelijke mate van zekerheid geven dat de financiële verslaggeving van het lopende jaar geen onjuistheden van materieel belang bevatten (met andere woorden voor het lopende jaar 2010, dit is als het ware een forward looking statement). Uit de context is niet goed op te maken of dit bewust of onbewust op deze wijze is geformuleerd

Z Wij wijzen er overigens op dat het aantal van twaalf niet hard is, gezien onze bevinding dat de omvang van het directieverslag niet altijd helder blijkt uit de opbouw van het jaarrapport. De mogelijkheid bestaat dat een aantal directies bedoeld heeft om de ondertekening samen te laten vallen, terwijl uit de opbouw lijkt of het een verklaring betreft welke buiten het directieverslag is geplaatst. Indien de bestuursverklaring wel in het directieverslag is geplaatst, maar niet net voor de ondertekening, hebben wij dit beschouwd als niet-expliciet ondertekend door directie.

\section{Literatuur}

Beurden, B van, en A. De Bos (2009), Volgen Richtlijn is soms ongewenst, Het Financieele Dagblad, 26 november 2009.

- Frijns, J. en W, Poesiat (2006), Eerste bevindingen van de Monitoring Commissie Corporate Governance Code. Alsmede aanbevelingen en accenten voor 2006 Maandblad voor Accountancy en Bedrijfseconomie, vol. 80, no. 5, pp. 216-218.

- Groot, J. de, en B. Koolstra (2006), De in-control good practice van de Commissie Frijns lost slecht een deel van de puzzel op, Maandblad voor Accountancy en Bedriffseconomie, vol. 80, no. $7 / 8$, pp. 392-400.
- Leeuwen, O. van, en P. Wallage (2010), Het evalueren van de interne beheersomgeving. Een onderbelicht thema, Maandblad voor Accountancy en Bedrijfseconomie, vol. 84, no. 9, pp. 447-457. - Lückerath-Rovers, M., M.A. Scheltema en A De Bos (2010), Het RvC verslag: weinig inzicht in toezicht, Maandblad voor Accountancy en Bedriffseconomie, vol. 84, no. 11, pp. 575-587. - Ridder, W.P. de, en J. Steggink (2009), Verantwoording over risicobeheersing. Wat willen aandeelhouders, banken en ondernemingsraden weten, Maandblad voor Accountancy en Bedrijfseconomie, vol. 83, no. 7/8, pp. 247-253.
- Sampers, P. (2005), Het 'in-control statement'. Eerste aanzet tot bestuursverklaring inzake interne beheersing voor Nederlandse beursfondsen, Maandblad voor Accountancy en Bedrijfseconomie, vol. 79, no. 7/8, pp. 361-369.

\section{Wet- en regelgeving}

Besluit tot vaststelling van nadere voorschriften omtrent de inhoud van het jaarverslag.

- Besluit artikel 10 Overnamerichtlijn.

Burgerlijk Wetboek.

Europees Parlement en de Raad (2004),

Richtlijn 2004/109/EG van het Europees

Parlement en de Raad, (Transparantie Richtlijn); zie: http://eur-lex.europa.eu.

Europees Parlement en de Raad (2006), Richtlijn 2006/46/EG van het Europees

Parlement en de Raad, (Corporate Governance Richtlijn); zie: http://eur-lex.europa.eu.
Koninklijk Nederlands Instituut voor Registeraccountants 'Praktijkhandreiking 1109: De verantwoordelijkheid van de accountant bij de toetsing van in het jaarverslag opgenomen corporate governance informatie': zie: www.nivra.nl.

- Monitoring Commissie Corporate Governance Code (2008), Nederlandse Corporate Governance Code. Beginselen van deugdelijk ondernemingsbestuur en best practice bepalingen; zie: www.corpgov.nl.
- Nota van toelichting bij: 'Besluit tot vaststelling van nadere voorschriften omtrent de inhoud van het jaarverslag'. - Raad voor de Jaarverslaggeving (2009), RJ-Uiting 2009-9 'Ontwerp-Richtlijn 400 Jaarverslag'; zie: www.rjnet.nl. - Wet op het financieel toezicht. 
De corporate governance-verklaring omvat:

1. Een uitspraak betreffende de naleving van de principes en best practice-bepalingen van de Code die zijn gericht tot het bestuur of de raad van commissarissen (artikel 3 lid 1 Besluit). Indien de vennootschap een of meerdere bepalingen niet naleeft in het huidig of daaropvolgend boekjaar, doet het bestuur hiervan een gemotiveerde opgave. Als de vennootschap naast de Code nog een andere gedragscode naleeft, dient hierover op dezelfde wijze verantwoording te worden afgelegd (artikel 3 lid 2 Besluit).

2. Een mededeling over de belangrijkste kenmerken van het beheers- en controlesysteem van de vennootschap met betrekking tot de financiële verslaggeving (artikel 3a.a Besluit).

3. Een mededeling over het functioneren van de aandeelhoudersvergadering en haar voornaamste bevoegdheden en rechten van de aandeelhouders en de wijze waarop zij deze rechten kunnen uitoefenen (artikel za.b Besluit).

4. Een mededeling over de samenstelling en het functioneren van het bestuur, de raad van commissarissen en de commissies van de raad van commissarissen (artikel 3a.c Besluit).

5. De volgende informatie als gevolg van het Besluit artikel 10 Overnamerichtlijn (artikel $3 \mathrm{~b}$ Besluit):

- de deelnemingen in de vennootschap waarvoor een meldingsplicht bestaat overeenkomstig de artikelen 5:34, 5:35 en 5:43 van de Wft (Besluit artikel 10 Overnamerichtlijn artikel 1:1.c);

- de bijzondere zeggenschapsrechten verbonden aan aandelen en de naam van de gerechtigde (Besluit artikel 10 Overnamerichtlijn artikel 1.d);

- elke beperking van stemrecht, termijnen voor de uitoefening van stemrecht en de uitgifte, met medewerking van de vennootschap, van certificaten van aandelen (Besluit artikel 1o Overnamerichtlijn artikel 1.f);

- de voorschriften betreffende benoeming en ontslag van bestuurders en commissarissen en wijziging van de statuten (Besluit artikel 10 Overnamerichtlijn artikel 1.h);

- de bevoegdheden van het bestuur, in het bijzonder tot de uitgifte van aandelen van de vennootschap en de verkrijging van eigen aandelen door de vennootschap (Besluit artikel 10 Overnamerichtlijn artikel 1.i).

6. Lijst van namen met een bijzonder statutair recht op het gebied van de zeggenschap, met de aard van dat recht tenzij deze informatie is opgenomen onder de overige gegevens als gevolg van artikel 392 lid 1.e. 
Bijlage 2 Overzicht van relevante wet- en regelgeving

\begin{tabular}{|c|c|c|c|c|}
\hline Onderwerp & Code & Besluit & WFT & $\begin{array}{l}\text { Overige } \\
\text { wet- en regelgeving }\end{array}$ \\
\hline $\begin{array}{l}\text { Opname verklaring inzake corporate governance als onderdeel of bijlage bij bestuursverslag, of } \\
\text { geplaatst op de website }\end{array}$ & & $2 \mathrm{a}$ & & \\
\hline Hoofdlijnen van de corporate governance-structuur in een afzonderlijk hoofdstuk & 1.1 & & & \\
\hline Hoofdzaken maatschappelijk verantwoord ondernemen opnemen in jaarverslag & |ll.1.2 & & & RJ 400.113-122 \\
\hline Beschrijving strategische risico's & |l.1.4 & & & RJ $400.110 \mathrm{~A}$ \\
\hline Beschrijuing operationele risico's & |l.1.4 & & & RJ 400.110A \\
\hline Beschrijving financiële risico's & |ll.1.4 & & & RJ $400.110 A$ \\
\hline Beschrijving verslaggevingrisico's & |l.1.4 & 3a sub a & & RJ 400.110A \\
\hline Beschrijving compliancerisico's & |ll.1.4 & & & RJ 400.110A \\
\hline In-control statement verslaggevingsrisico's & |l.1.5 & & & \\
\hline Getrouw beeld verklaring & & & $5: 25 c$ & RJ 400.207 \\
\hline Uitspraak comply or explain-principes en best practice-bepalingen Code & 1.1 & 3.1 & & \\
\hline Mededeling over functioneren AVA & & 3a sub b & & $\begin{array}{l}\text { 1:1 c, d, h, f en i } \\
\text { Besluit art } 10 \\
\text { Overname Richtlijn }\end{array}$ \\
\hline Voornaamste bevoegdheden en rechten van de AVA & & 3a sub b & & $\begin{array}{l}\text { 1:1 c, d, h, f en i } \\
\text { Besluit art } 10 \\
\text { Overname Richtlijn }\end{array}$ \\
\hline Mededeling van de wijze waarop aandeelhouders deze rechten kunnen uitoefenen & & 3a sub b & & $\begin{array}{l}\text { 1:1 c, d, h, f en i } \\
\text { Besluit art } 10 \\
\text { Overname Richtlijn }\end{array}$ \\
\hline Samenstelling bestuur & & 3a sub c & & \\
\hline Mededeling functioneren bestuur & & 3a sub c & & \\
\hline Samenstelling RVC & |III.1.3 & 3a sub c & & \\
\hline Mededeling functioneren RvC & 111.5 & 3a sub c & & \\
\hline Samenstelling commissies RvC & |III.5.2 & 3a sub c & & \\
\hline Mededeling functioneren commissies RvC & & 3a sub c & & \\
\hline $\begin{array}{l}\text { Deelnemingen in de vennootschap waarvoor een meldingsplicht bestaat overeenkomstig de } \\
\text { artikelen 5:34, 5:35 en 5:43 van de Wft }\end{array}$ & & $3 b$ & & $\begin{array}{l}\text { 1:1c Besluit art } 10 \\
\text { Overname Richtlijn }\end{array}$ \\
\hline Bijzondere zeggenschapsrechten verbonden aan aandelen en de naam van de gerechtigde & & $3 b$ & & $\begin{array}{l}\text { 1:1d Besluit art } 10 \\
\text { Overname Richtlijn }\end{array}$ \\
\hline $\begin{array}{l}\text { Elke beperking van stemrecht, termijnen voor de uitoefening van stemrecht en de uitgifte, met } \\
\text { medewerking van de vennootschap, van certificaten van aandelen }\end{array}$ & & $3 b$ & & $\begin{array}{l}\text { 1:1f Besluit art } 10 \\
\text { Overname Richtlijn }\end{array}$ \\
\hline $\begin{array}{l}\text { De voorschriften betreffende benoeming en ontslag van bestuurders en commissarissen en } \\
\text { wijziging van de statuten }\end{array}$ & & $3 b$ & & $\begin{array}{l}\text { 1:1h Besluit art } 10 \\
\text { Overname Richtlijn }\end{array}$ \\
\hline $\begin{array}{l}\text { De bevoegdheden van het bestuur, in het bijzonder tot de uitgifte van aandelen van de } \\
\text { vennootschap en de verkrijging van eigen aandelen door de vennootschap }\end{array}$ & & $3 b$ & & $\begin{array}{l}\text { 1:1i Besluit art } 10 \\
\text { Overname Richtlijn }\end{array}$ \\
\hline $\begin{array}{l}\text { Een lijst van namen met een bijzonder statutair recht op het gebied van de zeggenschap, met de } \\
\text { aard van dat recht tenzij deze informatie is opgenomen onder de overige gegevens }\end{array}$ & & $3 b$ & & 392 lid 1e BW 2 \\
\hline
\end{tabular}


Bijlage 3 Ondernemingen in het onderzoek

\begin{tabular}{|l|l|c|}
\hline 1 & AEGON & AEX \\
\hline 2 & Ahold & AEX \\
\hline 3 & AkzoNobel & AEX \\
\hline 4 & ASML & AEX \\
\hline 5 & BAM & AEX \\
\hline 6 & Boskalis & AEX \\
\hline 7 & Corio & AEX \\
\hline 8 & DSM & AEX \\
\hline 9 & Fugro & AEX \\
\hline 10 & Heineken & AEX \\
\hline 11 & ING & AEX \\
\hline 12 & KPN & AEX \\
\hline 13 & Philips & AEX \\
\hline 14 & Randstad & AEX \\
\hline 15 & Royal Dutch Shell & AEX \\
\hline 16 & SBM Offshore & AEX \\
\hline 17 & TNT & AEX \\
\hline 18 & Unibail-Rodamco & AEX \\
\hline 19 & Unilever & AEX \\
\hline 20 & Wereldhave & AEX \\
\hline 21 & Wolters Kluwer & AEX \\
\hline 22 & Aalberts Industries & AMX \\
\hline & & \\
\hline
\end{tabular}

\begin{tabular}{|l|l|c|}
\hline 23 & AMG & AMX \\
\hline 24 & Arcadis & AMX \\
\hline 25 & Asm International & AMX \\
\hline 26 & Binckbank & AMX \\
\hline 27 & Crucell & AMX \\
\hline 28 & CSM & AMX \\
\hline 29 & Delta Lloyd & AMX \\
\hline 30 & Draka Holding & AMX \\
\hline 31 & Eurocommercial Properties & AMX \\
\hline 32 & Heijmans & AMX \\
\hline 33 & Imtech & AMX \\
\hline 34 & Koninklijke Ten Cate & AMX \\
\hline 35 & Mediq & AMX \\
\hline 36 & Nutreco & AMX \\
\hline 37 & Ordina & AMX \\
\hline 38 & Smit International & AMX \\
\hline 39 & Sns Reaal & AMX \\
\hline 40 & USG People & AMX \\
\hline 41 & Vastned Retail & AMX \\
\hline 42 & Vopak & AMX \\
\hline 43 & Wavin & AMX \\
\hline 44 & Wessanen & AMX \\
\hline & & \\
\hline
\end{tabular}

